\title{
In vitro studies on the effect of watercress juice on digestive enzymes relevant to type 2 diabetes and obesity and antioxidant activity
}

\author{
Vítor Spínola | Joana Pinto | Paula C. Castilho
}

CQM-Centro de Química da Madeira, Universidade da Madeira, Campus da Penteada, Funchal 9020-105, Portugal

\section{Correspondence}

Paula C. Castilho, CQM-Centro de Química da Madeira, Universidade da Madeira, Campus da Penteada, Funchal 9020-105, Portugal.

Email: castilho@uma.pt

Funding information

Fundação para a Ciência e a Tecnologia funds from Portuguese Government, Grant/ Award Number/Project: PEst-OE/QUI/ UI0674/2013; Portuguese National Mass Spectrometry Network, Grant/Award Number/Contract: RNEMREDE/1508/ REM/2005

\begin{abstract}
Inhibition of enzymes involved in carbohydrate and lipids metabolism is an important strategy against type 2 diabetes and obesity, by suppressing dietary sugar and fat absorption. This work reports, for the first time, the in vitro inhibition of $\alpha$-glucosidase, $\alpha$-amylase and lipase by watercress juice (WJ). Juice was analyzed for qualitative and quantitative composition and in vitro antioxidant activities. Several components were identified, namely hydroxycinnamic acids, flavonols, and other minor water-soluble phytochemicals. Quantitative data revealed a dimer of caffeoylmalic acid (0.73 $\mathrm{mg} \mathrm{mL}^{-1}$ of juice), disinapoylgentibiose $\left(0.64 \mathrm{mg} \mathrm{mL}^{-1}\right)$, ferulic acid (0.56 mg mL $\left.{ }^{-1}\right)$, and isorhamnetin-O-sophoroside-O-malonyl(hexoside) $\left(0.38 \mathrm{mg} \mathrm{mL}^{-1}\right.$ ) as the predominant polyphenols. The results showed that WJ had dose-dependent inhibitory potential against targeted enzymes, displaying a more potent inhibitory effect against $\alpha$-glucosidase relative to $\alpha$-amylase and lipase. WJ can be considered a potential complementary dietary approach to control hyperglycaemia and hyperlipidaemia, through inhibition of digestive enzymes.
\end{abstract}

\section{Practical applications}

Currently, raw watercress is widely consumed in liquid form, alone or together with other fresh vegetables, as an ingredient of the "detox juices." Studies on watercress phenolic composition and antidiabetic properties have been performed on extracts, but not on juice, which is closer to the edible form. The present study supports consumption of watercress juice as source of phytochemicals potentially capable of inhibiting digestive enzymes linked to diabetes and obesity prevention/control.

\section{KEYWORDS}

antioxidant activity, digestive enzymes inhibition, hyperglycaemia, phenolic compounds, watercress

\section{1 | INTRODUCTION}

Excessive weight and obesity can lead to type 2 diabetes (T2D) which is rapidly becoming a major health problem worldwide (Mahmood, 2015). In most diets, carbohydrates are the main source of calories. Inhibition of carbohydrate digestive enzymes is an effective mechanism for the management of hyperglycaemia in T2D by retarding carbohydrates digestion and absorption to promote weight loss (Mahmood, 2015; Podsedek, Majewska, Redzynia, Sosnowska, \& Koziołkiewicz, 2014). Commercially available synthetic inhibitors like acarbose, voglibose, and miglitol can cause adverse health effects such as abdominal pain, flatulence, diarrhea, and liver damage to diabetic patients (Simsek,
EL, Kancabas Kilinc, \& Karakaya, 2014). Therefore, inhibition of $\alpha$-glucosidase and $\alpha$-amylase by dietary polyphenols or isolated phenolic compounds from plant derived foods may offer an alternative natural approach for control and management of glycaemia in T2D (Arulselvan et al., 2014). Phenolic compounds are also known to interfere with pancreatic lipase activity (Alakolanga, Kumar, Jayasinghe, \& Fujimoto, 2015; Kim et al., 2010; Mahmood, 2015), thus limiting fat absorption in the intestinal lumen.

A diet rich in fruits and vegetables has been associated with several health benefits in humans, not only due to the presence of large amounts of fiber but also to substances with antioxidant activity (Isabelle et al., 2010; Simsek et al., 2014; Tiwari et al., 2013; 
Vinha, Alves, Barreira, Costa, \& Oliveira, 2015). Vegetable juices are a natural dietary source of polyphenols, often used as a low-sugar alternative to fruit juice. Watercress (Nasturtium officinale W. T. Aiton; syn: Rorippa nasturtium-aquaticum, Brassicaceae) is an aquatic leafy vegetable with great economic importance in Portugal: about 5.000 tons per year are exported to countries in Northern Europe. Usually, the raw leaves are consumed fresh as salad greens or steamed and consumed as other vegetables (Mousa-Al-Reza Hadjzadeh, Moradi, \& Ghorbani, 2015). Currently, it is widely consumed fresh in liquid form, alone or together with other fresh vegetables, as a trendy ingredient of the so called "detox juices" (Escardó \& Cuadra, 2014).

Although, previous studies (Aires, Carvalho, Rosa, \& Saavedra, 2013; Boligon et al., 2013; Isabelle et al., 2010; Martínez-Sánchez, GilIzquierdo, Gil, \& Ferreres, 2008; Payne, Mazzer, Clarkson, \& Taylor, 2013; Pereira, Barros, Carvalho, \& Ferreira, 2011; Santos, Oliveira, Ibáñez, \& Herrero, 2014; Tiveron et al., 2012) have reported the phenolic composition and antioxidant activities of watercress, this vegetable is still one of the least studied Brassica species (Cartea, Francisco, Soengas, \& Velasco, 2011). Claims on watercress antidiabetic properties have been made, validating its use in folk medicine as a hypoglycemic plant (Mousa-Al-Reza Hadjzadeh et al., 2015; Shahrokhi, Hadad, Keshavarzi, \& Shabani, 2009). However, these assays were performed with hydroalcoholic extracts in which active substances were concentrated, but not on juice, which is more relevant to the human digestive system and diet.

Previously, the vitamin C content in watercress juice (WJ) and its stability with time and temperature was determined (Spínola, Mendes, Câmara, \& Castilho, 2013). The aim of the present study was to further characterize its phytochemical profile and assess its in vitro inhibitory effect against key enzymes linked to T2DM and obesity ( $\alpha$-glucoside, $\alpha$-amylase, and lipase) as well as its antioxidant activity.

\section{2 | MATERIALS AND METHODS}

\section{$2.1 \mid$ Chemicals and standards}

The following reagents were purchased from Panreac (Barcelona, Spain): Folin-Ciocalteu's phenol reagent (FCR), sodium chloride, potassium chloride, L-ascorbic acid (L-AA) (>99\%), gallic acid (>98\%), quercetin (>99\%), and potassium acetate. 6-Hydroxy-2,5,7,8tetramethylchroman-2-carboxylic acid (Trolox) and 2,2' -azinobis-(3-ethylbenzthiazoline-6-sulfonic acid) (ABTS) were obtained from Fluka (Lisbon, Portugal). Caffeic acid (>98\%, HPLC), protocatechuic acid (98\%, HPLC), fluorescein disodium salt, potassium persulfate, sodium carbonate, 2,20-azobis(2-methyl propionamidine) dihydrochloride (AAPH), $\alpha$-glucosidase from Saccharomyces cerevisiae (type I), $\alpha$-amylase from porcine pancreas (type VI-B), lipase (type II; from porcine pancreas), $p$ nitrophenyl- $\alpha$-D-glucopyranoside ( $p N P G), \quad p$-nitrophenyl butyrate ( $p N P B)$, and formic acid from Sigma-Aldrich (St. Louis, MO, USA). Aluminum chloride hexahydrate and sodium hydrogen phosphate were obtained from Riedel-de Haën (Hanover, Germany); potassium dihydrogen phosphate and starch from Merck (Darmstadt, Germany). LC-MS grade acetonitrile $\left(\mathrm{CH}_{3} \mathrm{CN}\right)$ (LabScan; Dublin, Ireland) and ultrapure water (Milli-Q water purification system, Millipore, USA) were used for analysis. Acarbose (Acarbose Generis ${ }^{\circledR}$ ) and orlistat (Ratiopharm ${ }^{\circledR}$ ) were purchased from a drug store.

\section{2 | Sample preparation}

Watercress (var. Hampshire) was grown in Madeira Island (Portugal) by different producers and supplied to Organic Chemistry and Natural Products Laboratory (NatLab, CQM) two days after harvest, in bunches of about $500 \mathrm{~g}$ each (total $3 \mathrm{~kg}$ ). Portions of watercress leaves and tender stalks were collected from each bunch, mixed, and homogenized in a prechilled blender and the homogenates were centrifuged for $30 \mathrm{~min}$ $\left(10,000 \mathrm{rpm} ; 2-4^{\circ} \mathrm{C}\right)$ (Spínola et al., 2013). Supernatants were filtered, and the resulting liquid (raw extract, from now on designated as "juice") was stored at $-80^{\circ} \mathrm{C}$. Three batches were obtained by this procedure.

Total soluble solids were determined using an Atago RX-1000 digital refractometer and the result $\left(2.5^{\circ} \mathrm{Brix}\right)$ was similar to that reported previously for watercress (Vinha et al., 2015).

\section{3 | Chromatographic conditions}

HPLC analysis was carried out on a Dionex ultimate 3000 series instrument coupled to a binary pump, a diode-array detector (DAD), an autosampler and a column compartment (kept at $20^{\circ} \mathrm{C}$ ). Separation was performed on a Phenomenex Gemini $\mathrm{C}_{18}$ column $(5 \mu \mathrm{m}, 250 \times 3.0 \mathrm{~mm}$ i.d.) using a mobile phase composed of $\mathrm{CH}_{3} \mathrm{CN}(\mathrm{A})$ and formic acid/ water $(0.1 \%, v / v)$ at a flow rate of $0.4 \mathrm{~mL} \mathrm{~min}^{-1}$. The following gradient program was used: 20\% A (10 min), 25\% A (20 min), 50\% A (40 min), 100\% A (42-47 min), and 20\% A (49-55 min). Spectral data for all peaks were accumulated in the range of $210-400 \mathrm{~nm}$. Juice was diluted with the initial eluent gradient (dilution 1/10), filtered through $(0.45 \mu \mathrm{m})$ and $10 \mu \mathrm{L}$ were injected directly.

For HPLC-DAD/ESI-MS ${ }^{n}$ analysis, a Bruker Esquire model 6000 ion trap mass spectrometer (Bremen, Germany) with an ESI source was used. $\mathrm{MS}^{n}$ analysis was performed in negative mode and the scan range was set at $\mathrm{m} / \mathrm{z} 100-1,000$ with a speed of $13,000 \mathrm{Da} \mathrm{s}^{-1}$. The conditions of ESI were as follows: drying and nebulizer gas $\left(\mathrm{N}_{2}\right)$ flow rate

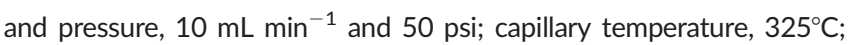
capillary voltage, $4.5 \mathrm{keV}$; collision gas $(\mathrm{He})$ pressure and energy, $1 \times 10^{-5} \mathrm{mbar}$ and $40 \mathrm{eV}$; and fragmentor, $1.0 \mathrm{eV}$. Esquire control software was used for data acquisition and Data Analysis software for processing.

\section{4 | Quantitative determination of polyphenols}

Quantification of main polyphenols was carried out by HPLC-DAD, based on a previous method (Díaz-García, Obon, Castellar, Collado, \& Alacid, 2013). Caffeic acid, protocatechuic acid, and quercetin were used for hydroxycinnamic, hydroxybenzoic acids, and flavonols quantification, respectively. Calibration curves (5-100 $\mathrm{mg} \mathrm{L}^{-1}$ ) were prepared by diluting the stock solutions (1,000 $\mathrm{mg} \mathrm{L}^{-1}$ in methanol) with initial mobile phase. Quantification was carried out by plotting peak area versus concentration $\left(R^{2} \geq 0.967\right.$ in all cases). 


\section{$2.5 \mid \alpha$-Glucosidase inhibition assay}

This assay was adapted from a previous report (Podsedek et al., 2014). In a 96-well plate, $50 \mu \mathrm{L}$ of juice (serial dilutions) was combined with $50 \mu \mathrm{L}$ of enzyme solution $\left(0.1 \mathrm{mg} \mathrm{mL}^{-1}\right.$ in $0.1 \mathrm{~mol} \mathrm{~L}^{-1}$ phosphate buffer; $\mathrm{pH}$ 6.9) and incubated for $20 \mathrm{~min}$. The reaction was initiated by adding $50 \mu \mathrm{L}$ of $5 \mathrm{mmol} \mathrm{L} \mathrm{L}^{-1}$ pNPG solution in the above buffer. The mixture was incubated at $37^{\circ} \mathrm{C}$ for $20 \mathrm{~min}$. Finally, $100 \mu \mathrm{L}$ of $0.1 \mathrm{~mol} \mathrm{~L}^{-1} \mathrm{Na}_{2} \mathrm{CO}_{3}$ solution was added and the absorbance was read at $405 \mathrm{~nm}$ (Victor ${ }^{3}$ microtiter reader; Perkin-Elmer, Ueberlingen, Germany). Inhibition (IC $\mathrm{C}_{50}$ value) of juices was expressed in terms of acarbose equivalent $(\mathrm{AE})$ concentration ( $\mathrm{mg} \mathrm{AE} \mathrm{mL}^{-1}$ solution) (Tiwari et al., 2013), and acarbose was used as positive control.

\section{$2.6 \mid \alpha$-Amylase inhibition assay}

The assay was performed as described previously (Podsedek et al., 2014), with slight modifications: $20 \mu \mathrm{L}$ of juice (serial dilutions) and $40 \mu \mathrm{L}$ of $2 \mathrm{~g} \mathrm{~L}^{-1}$ starch solution were mixed with $20 \mu \mathrm{L}$ of $\alpha$-amylase (0.1 $\mathrm{mg} \mathrm{mL}^{-1}$ in $0.1 \mathrm{~mol} \mathrm{~L}^{-1}$ phosphate buffer; $\mathrm{pH}$ 6.9). After incubation at $37^{\circ} \mathrm{C}$ for $20 \mathrm{~min}$, the reaction was stopped by addition of $80 \mu \mathrm{L}$ of $0.4 \mathrm{~mol} \mathrm{~L}^{-1} \mathrm{HCl}$ followed by $100 \mu \mathrm{L}$ of $5 \mathrm{mmol} \mathrm{L}^{-1} \mathrm{I}_{2}$ (in $5 \mathrm{mmol} \mathrm{L}^{-1} \mathrm{KI}$ ), and the absorbance was read at $620 \mathrm{~nm}\left(\right.$ Victor $^{3}$ microtiter reader; Perkin-Elmer). Acarbose was used as positive control and inhibition ( $\mathrm{IC}_{50}$ value) was expressed as described previously.

\section{7 | Lipase inhibition assay}

The method for measuring lipase activity was based on a previous protocol (Kim et al., 2010): $40 \mu \mathrm{L}$ of juice was mixed with $20 \mu \mathrm{L}$ of $10 \mathrm{mM}$ of $p$ NPB solution and $40 \mu \mathrm{L}$ of the enzyme $\left(2.5 \mathrm{mg} \mathrm{mL}^{-1}\right.$ prepared in $0.1 \mathrm{M}$ phosphate buffer; $\mathrm{pH}$ 8.0). After incubation $\left(20 \mathrm{~min} ; 37^{\circ} \mathrm{C}\right.$ ), absorbance was read at $405 \mathrm{~nm}$ (Victor ${ }^{3}$ microtiter reader; PerkinElmer). Orlistat was used as positive control and inhibitory activity ( $\mathrm{IC}_{50}$ value) was expressed in terms of orlistat equivalent (OE) concentration (mg OE $\mathrm{mL}^{-1}$ solution).

\section{8 | Total phenolic content (TPC)}

The method was adapted from previous reports (Isabelle et al., 2010): $50 \mu \mathrm{L}$ of sample was mixed with $1.25 \mathrm{~mL}$ of FCR (diluted 1:10) and $1 \mathrm{~mL}$ of $75 \mathrm{~g} \mathrm{~L}^{-1} \mathrm{Na}_{2} \mathrm{CO}_{3}$, added to a $5 \mathrm{~mL}$ test tube and mixed. After $30 \mathrm{~min}$, absorbance of the reaction mixture was measured at $765 \mathrm{~nm}$ (UV-Vis Lambda 2 spectrophotometer, Perkin Elmer, Oberlingen, Germany). The amount of total phenolics was expressed as mg of gallic acid equivalents (GAE) $\mathrm{mL}^{-1}$ of juice.

\section{9 | Total flavonoid content (TFC)}

TFC was measured using a published method (Aires et al., 2013), with adaptations: $0.5 \mathrm{~mL}$ of sample was mixed with $1.5 \mathrm{~mL}$ of methanol, $2.8 \mathrm{~mL}$ of deionized water, $0.1 \mathrm{~mL}$ of $\mathrm{CH}_{3} \mathrm{COOK}(1 \mathrm{M})$ and $0.1 \mathrm{~mL}$ of $\mathrm{AlCl}_{3} \cdot 6 \mathrm{H}_{2} \mathrm{O}(10 \%$ in $\mathrm{MeOH})$. After $30 \mathrm{~min}$, absorbance of the reaction mixture was measured at $415 \mathrm{~nm}$ (Lambda 2 spectrophotometer, Per-
kin-Elmer). The results were expressed as $\mathrm{mg}$ of quercetin equivalent (QCE) $\mathrm{mL}^{-1}$ of juice.

\subsection{0 | ABTS radical scavenging activity}

The ABTS $^{+}$assay used was a modified version (Tiveron et al., 2012): $40 \mu \mathrm{L}$ of sample was added to $1.96 \mathrm{~mL}$ of the $\mathrm{ABTS}^{++}$solution (diluted in PBS, pH 7.4; absorbance $0.700 \pm 0.021$ ). The reduction of absorbance at $734 \mathrm{~nm}$ (Lambda 2 spectrophotometer, Perkin-Elmer) was measured for $6 \mathrm{~min}$. Results were expressed as $\mu \mathrm{mol}$ Trolox equivalent (TE) $\mathrm{mL}^{-1}$ juice, based on the Trolox calibration curve.

\subsection{1 | Oxygen radical absorbance capacity (ORAC) assay}

The ORAC assay followed a reported method with some modifications (Isabelle et al., 2010): $25 \mu \mathrm{L}$ of juice was transferred to the microplate, containing blank (200 $\mu \mathrm{L}$ of PBS) and control ( $25 \mu \mathrm{L}$ of PBS) wells. Then, $150 \mu \mathrm{L}$ of $40 \mathrm{nmol} \mathrm{L}{ }^{-1}$ fluorescein (in PBS, 7.4) was added to the control and sample wells. After incubation $\left(37^{\circ} \mathrm{C}, 30 \mathrm{~min}\right), 25 \mu \mathrm{L}$ AAPH (153 mmol L ${ }^{-1}$ in PBS) was added to wells with the exception of the blank. Fluorescence readings $\left(\lambda_{\mathrm{em}}=485 \mathrm{~nm} ; \lambda_{\mathrm{ex}}=535 \mathrm{~nm}\right)$ were taken every minute for 60 min $\left(\right.$ Victor $^{3}$ microtiter reader; PerkinElmer) and results were expressed as $\mu \mathrm{mol} \mathrm{TE} \mathrm{mL}^{-1}$ juice, based on the Trolox calibration curve.

\subsection{2 | Statistical analysis}

All samples were assayed in triplicate $(n=3)$ and results were given as the means \pm standard deviations. Data were analyzed by means of a oneway ANOVA using SPSS for Windows, IBM SPSS Statistics 20 (SPSS, Inc., USA). A value of $p<0.05$ was considered statistically significant.

\section{3 | RESULTS AND DISCUSSION}

\section{1 | Phytochemical composition}

In this study, identification of phytochemicals was assigned by combining the DAD and mass spectrometry data obtained under negative electron spray ionization $\left(\mathrm{ESI}^{-}\right)$together with scientific information available in literature (Table 1).

Compounds were numbered by their elution order and a total of 40 compounds were detected (Fig. S1). These were mainly polyphenols (in particular hydroxycinnamic acids [HCAs]) but other phytochemicals were detected as minor constituents (organic acids, terpenoid, lignan and oligosaccharides). This is the first report of some of these compounds in watercress. With the exception of roseoside, the remaining compounds have been characterized previously in other Brassica vegetables (Harbaum et al., 2007; Lin \& Harnly, 2010; Olsen, Aaby, \& Borge, 2009).

Phenolic acids were dominant polyphenols, with some of them detected in free form, while others were conjugated with different glycoside residues: caffeic, $p$-coumaric, sinapic and ferulic acids, and ferulic acid-O-hexoside. Disinapoylgentiobiose and sinapoylferuloylgentibiose (compounds 28 and $\mathbf{3 3}$ ) were identified for the first time in watercress, 
TABLE 1 Identification and quantification of water-soluble phytochemicals from watercress juice (Q: quercetin; I: isorhamnetin)

\begin{tabular}{|c|c|c|c|c|c|c|c|}
\hline Number & $\begin{array}{l}t_{R} \\
(\mathrm{~min})\end{array}$ & $\begin{array}{l}\lambda_{\max } \\
(\mathrm{nm})\end{array}$ & $\begin{array}{l}{[\mathrm{M}-\mathrm{H}]^{-}} \\
(\mathrm{m} / \mathrm{z})\end{array}$ & $\begin{array}{l}\mathrm{MS}^{n} \text { fragments } \\
(\mathrm{m} / \mathrm{z})\end{array}$ & Assigned identity & References & $\begin{array}{l}\text { Concentration } \\
\text { ( } \mathrm{mg} \mathrm{mL}^{-1} \text { juice) }\end{array}$ \\
\hline 1 & 2.9 & - & 561 & $\begin{array}{l}415,179,161 \\
143,119,89\end{array}$ & Saccharide & - & \\
\hline 2 & 3.1 & - & 179 & $\begin{array}{l}161,143,119 \\
113,89\end{array}$ & Hexose & $\begin{array}{l}\text { Verardo, Duse, } \\
\text { and Callea (2009) }\end{array}$ & \\
\hline 3 & 3.6 & 215 & 133 & 115 & Malic acid & $\begin{array}{l}\text { Spínola, Pinto, and } \\
\text { Castilho (2015) }\end{array}$ & \\
\hline 5 & 4.4 & 268,354 & 711 & $\begin{array}{l}667,505,301 \\
179,151\end{array}$ & $\begin{array}{l}\text { Q-O-hexoside-O- } \\
\text { (malonyl)hexoside }\end{array}$ & $\begin{array}{l}\text { Llorach et al. } \\
(2008)\end{array}$ & $0.091 \pm 0.005$ \\
\hline 6 & 4.7 & 230,301 & 315 & 153,109 & $\begin{array}{l}\text { Protocatechuic } \\
\text { acid-O-hexoside }^{\text {a }}\end{array}$ & $\begin{array}{l}\text { Spínola et al. } \\
\text { (2015) }\end{array}$ & $0.097 \pm 0.005$ \\
\hline 9 & 6.7 & - & 933 & $\begin{array}{l}625,301,179 \\
151\end{array}$ & $\begin{array}{l}\text { Q-O-sophoroside- } \\
\text { O-rutinoside }\end{array}$ & Olsen et al. (2009) & $0.142 \pm 0.001$ \\
\hline 10 & 6.9 & - & 383 & $\begin{array}{l}267,193,149, \\
134\end{array}$ & $\begin{array}{l}\text { Ferulic acid deri- } \\
\text { vative }\end{array}$ & - & \\
\hline 11 & 7.7 & - & 787 & $\begin{array}{l}623,301,179 \\
151\end{array}$ & $\begin{array}{l}\text { Q-O-(coumaroyl) } \\
\text { sophoroside }\end{array}$ & - & $0.034 \pm 0.002$ \\
\hline 12 & 7.9 & - & 609 & $301,179,151$ & $\begin{array}{l}\text { Q-O-rutinoside } \\
\text { (rutin) }\end{array}$ & $\begin{array}{l}\text { Llorach, Martínez- } \\
\text { Sánchez, Tomás- } \\
\text { Barberán, and Gil } \\
\text { (2008) }\end{array}$ & $0.129 \pm 0.007$ \\
\hline 13 & 8.3 & 243,329 & 591 & $295,179,135$ & $\begin{array}{l}\text { Dimer of caffeoyl } \\
\text { malic acid }\end{array}$ & - & \\
\hline 17 & 9.5 & - & 831 & $\begin{array}{l}669,315,301, \\
271\end{array}$ & $\begin{array}{l}\text { I-O-hydroxyferu- } \\
\text { loylhexoside-O- } \\
\text { hexoside }\end{array}$ & $\begin{array}{l}\text { Lin and Harnly } \\
(2010)\end{array}$ & \\
\hline 18 & 9.6 & - & 463 & $301,179,151$ & Q-O-hexoside & $\begin{array}{l}\text { Llorach et al. } \\
\text { (2008) }\end{array}$ & $0.141 \pm 0.008$ \\
\hline 19 & 9.8 & - & 947 & $\begin{array}{l}639,315,300, \\
271\end{array}$ & $\begin{array}{l}\text { I-O-sophoroside- } \\
\text { O-rutinoside }\end{array}$ & $\begin{array}{l}\text { Martínez-Sánchez } \\
\text { et al. (2008) }\end{array}$ & \\
\hline 20 & 10.4 & - & 505 & $\begin{array}{l}389,191,179 \\
149\end{array}$ & $\begin{array}{l}\text { Ferulic acid deri- } \\
\text { vative }\end{array}$ & - & \\
\hline 21 & 10.6 & - & 771 & $\begin{array}{l}609,301,179 \\
151\end{array}$ & Rutin-O-hexoside & $\begin{array}{l}\text { Santos et al. } \\
\text { (2014) }\end{array}$ & $0.088 \pm 0.003$ \\
\hline 22 & 10.6 & - & 340 & $175,115,87$ & $\begin{array}{l}\text { L-Ascorbic acid } \\
\text { derivative }\end{array}$ & - & \\
\hline 23 & 10.7 & - & 801 & $\begin{array}{l}639,315,300, \\
271\end{array}$ & $\begin{array}{l}\text { I-O-sophoroside- } \\
\text { O-hexoside }\end{array}$ & $\begin{array}{l}\text { Martínez-Sánchez } \\
\text { et al. (2008) }\end{array}$ & $0.085 \pm 0.005$ \\
\hline 24 & 11.4 & 233,315 & 917 & $\begin{array}{l}872,669,315 \\
300,271\end{array}$ & $\begin{array}{l}\text { I-O-hydroxyferu- } \\
\text { loylhexoside-O- } \\
\text { malonyl(hexoside) }\end{array}$ & - & $0.013 \pm 0.001$ \\
\hline 25 & 11.6 & 225,310 & 163 & 119 & $p$-coumaric acida & Olsen et al. (2009) & $0.196 \pm 0.004$ \\
\hline
\end{tabular}


TABLE 1 (Continued)

\begin{tabular}{|c|c|c|c|c|c|c|c|}
\hline Number & $\begin{array}{l}t_{R} \\
(\min )\end{array}$ & $\begin{array}{l}\lambda_{\max } \\
(\mathrm{nm})\end{array}$ & $\begin{array}{l}{[\mathrm{M}-\mathrm{H}]^{-}} \\
(\mathrm{m} / \mathrm{z})\end{array}$ & $\begin{array}{l}M S^{n} \text { fragments } \\
(m / z)\end{array}$ & Assigned identity & $\begin{array}{l}\text { References } \\
\text { et al. (2008) }\end{array}$ & $\begin{array}{l}\text { Concentration } \\
\text { ( } \mathrm{mg} \mathrm{mL}^{-1} \text { juice) }\end{array}$ \\
\hline 27 & 12.0 & - & 339 & $\begin{array}{l}223,208,179 \\
164\end{array}$ & $\begin{array}{l}\text { Sinapoylmalic } \\
\text { acid }^{\mathrm{a}}\end{array}$ & $\begin{array}{l}\text { Harbaum et al. } \\
\text { (2007) }\end{array}$ & \\
\hline 28 & 12.2 & 237,323 & 753 & $\begin{array}{l}529,223,203 \\
179\end{array}$ & $\begin{array}{l}\text { Disinapoylgentio- } \\
\text { biose }^{\mathrm{a}}\end{array}$ & $\begin{array}{l}\text { Harbaum et al. } \\
\text { (2007) }\end{array}$ & \\
\hline 29 & 12.4 & 251,331 & 193 & $178,149,134$ & Ferulic acid $^{a}$ & Olsen et al. (2009) & $0.556 \pm 0.003$ \\
\hline 31 & 12.8 & - & 309 & 193,133 & FeruloyImalic acid ${ }^{a}$ & $\begin{array}{l}\text { Harbaum et al. } \\
\text { (2007) }\end{array}$ & \\
\hline 32 & 13.0 & - & 501 & $\begin{array}{l}385,223,179 \\
135\end{array}$ & $\begin{array}{l}\text { Sinapoylmalic } \\
\text { acid-O-hexoside }^{\text {a }}\end{array}$ & - & \\
\hline 35 & 14.7 & & 561 & 357,151 & $\begin{array}{l}\text { Pinoresinol-O- } \\
\text { acetylhexoside }^{\text {a }}\end{array}$ & $\begin{array}{l}\text { Llorent-Martínez, } \\
\text { Spínola, Gouveia, } \\
\text { and Castilho } \\
\text { (2015) }\end{array}$ & \\
\hline 36 & 15.2 & - & 871 & $\begin{array}{l}827,623,315 \\
300,271\end{array}$ & $\begin{array}{l}\text { I-O-rutinoside-O- } \\
\text { (malonyl)hexoside }\end{array}$ & - & \\
\hline 37 & 15.9 & - & 753 & $529,223,164$ & $\begin{array}{l}\text { Disinapoylgentio- } \\
\text { biose }^{\mathrm{a}}\end{array}$ & $\begin{array}{l}\text { Harbaum et al. } \\
\text { (2007) }\end{array}$ & $0.643 \pm 0.005$ \\
\hline 38 & 16.0 & - & 519 & $315,300,271$ & $\begin{array}{l}\text { I-O-(acetyl)hexosi- } \\
\text { de }^{\mathrm{a}}\end{array}$ & - & \\
\hline
\end{tabular}

${ }^{\mathrm{a}}$ Reported in watercress for the first time.

although their presence had been described in broccoli and tronchuda cabbage (Cartea et al., 2011; Harbaum et al., 2007; Lin \& Harnly, 2010). Malic acid derivatives were identified according to previous studies in other Brassica vegetables (Harbaum et al., 2007; Lin \& Harnly, 2010; Santos et al., 2014). Except for caffeoylmalic acid, these compounds have not been documented in watercress.

Isorhamnetin glycosides characterized based on previous studies (Harbaum et al., 2007; Lin \& Harnly, 2010) were also present. Free kaempferol was identified in association with a formate adduct (probably from mobile phase). An L-AA derivative was tentatively characterized, by comparison with L-AA commercial standard.

\subsection{Quantitative analysis}

Seventeen main polyphenols from WJ were quantified (Table 1). It was not possible to quantify all identified compounds because they were present in trace amounts.

Caffeoylmalic acid was the dominant phenolic compound, followed by disinapoylgentibiose, ferulic acid, and isorhamnetin-O-sophorosideO-malonyl(hexoside). Other compounds were present in lower concentrations (<0.20 $\mathrm{g} \mathrm{mL}^{-1}$ juice). Santos et al. (2014) also found caffeoyl- malic acid as the major compound in watercress extracts, with flavonols as the main group of polyphenols and a significant presence of HCAs.

In another study (Boligon et al., 2013), higher content of HCAs (caffeic and chlorogenic acids) than flavonoids (rutin) was reported in watercress. In contrast, quercetin and kaempferol glycosydes were major phenolics in extracts of watercress leaves (Martínez-Sánchez et al., 2008). Aires et al. (2013) also reported rutin and isorhamnetin as dominant compounds in watercress extracts.

Oxalic acid (OA) content in watercress $\left(12.16 \mathrm{~g} \mathrm{~kg}^{-1}\right.$ fresh weight, FW) was at the lower end of the range found in literature (7.54$60.12 \mathrm{~g} \mathrm{~kg}^{-1}$ FW)(Khan et al., 2016; Pinela et al., 2016), although higher than that of leaves of Swiss chard, spinach, or beetroot analyzed under

TABLE $2 \quad I_{50}$ values of watercress inhibitory activity towards digestive enzymes

\begin{tabular}{llll} 
& $\alpha$-Glucosidase & $\alpha$-Amylase & Lipase $^{\mathrm{b}}$ \\
Watercress juice & $5.198 \pm 0.310^{\mathrm{a}}$ & $0.354 \pm 0.017^{\mathrm{a}}$ & $2.202 \pm 0.054^{\mathrm{b}}$ \\
Acarbose $\left(\mathrm{mg} \mathrm{mL}^{-1}\right)$ & $1.619 \pm 0.023$ & $0.022 \pm 0.002$ & - \\
\hline Orlistat $\left(\mathrm{mg} \mathrm{mL}^{-1}\right)$ & - & - & $0.473 \pm 0.009$
\end{tabular}

${ }^{\mathrm{a}} \mathrm{mg} \mathrm{AE} \mathrm{mL}^{-1}$ solution.

${ }^{\mathrm{b}} \mathrm{mg}$ OE $\mathrm{mL}^{-1}$ solution. 
TABLE 3 Total phenolic and flavonoid contents and in vitro antioxidant activities of watercress juice

\begin{tabular}{ll}
\hline TPC (mg GAE $\mathrm{mL}^{-1}$ juice) & $2.89 \pm 0.08$ \\
\hline TFC (mg RUE $\mathrm{mL}^{-1}$ juice) & $1.26 \pm 0.04$ \\
\hline ABTS ( $\mu \mathrm{mol} \mathrm{TE} \mathrm{mL}{ }^{-1}$ juice) & $18.08 \pm 0.22$ \\
ORAC ( $\mu \mathrm{mol} \mathrm{TE} \mathrm{mL}^{-1}$ juice) & $19.27 \pm 0.64$
\end{tabular}

same conditions (results not shown) and generally considered as "high OA containing vegetables" (Getting et al., 2013). OA has been reported as the main organic acid in watercress (Khan et al., 2016) and it is considered an antinutrient due to the reduction of dietary calcium bioavailability and formation of oxalate kidney calculus (Getting et al., 2013).

\section{3 | In vitro enzyme inhibition assays}

WJ was able to inhibit digestive enzymes in a dose-dependent manner with a stronger inhibitor effect on $\alpha$-glucosidase than $\alpha$-amylase and lipase activity (Table 2). Significant differences $(p<0.05)$ were found between WJ and positive controls (acarbose and orlistat) in tested assays.

The inhibitory effects of some of the main components of $\mathrm{WJ}$ on porcine pancreas $\alpha$-amylase activity had been previously reported. Ferulic, caffeic and sinapic acids showed higher $I C_{50}$ values (>0.86 $\mathrm{mg} \mathrm{L}^{-1}$ ) than acarbose (0.015 $\mathrm{mg} \mathrm{L}^{-1}$ ) (Funke \& Melzig, 2005). Ferulic acid was the third major component of WJ (17\%), which could explain the mild inhibition of WJ. Lo Piparo et al. (2008) showed that only compounds of the flavonol and flavone families inhibited human salivary $\alpha$-amylase, although their $\mathrm{IC}_{50}$ values were higher than that of acarbose (0.001 $\mathrm{mg} \mathrm{mL}^{-1}$ ).

Other bioactive compounds in WJ may contribute to these inhibitory activities. Roseoside, pinoresinol and their glycosides are known to be $\alpha$-glucosidase inhibitory agents (Kwon et al., 2014; Yang, Liang, Xie, \& Wei, 2016), while malic acid has been characterized as the active principle for inhibition of $\alpha$-glucosidase, $\alpha$-amylase and lipase from Flacourtia inermis Roxb fruits (Alakolanga et al., 2015).

Similar inhibitory effects towards digestive enzymes have been demonstrated by other vegetable juices (Kumar et al., 2015; Tiwari et al., 2013), while other studies (Abirami, Nagarani, \& Siddhuraju, 2014; Lee et al., 2013; Simsek et al., 2014) documented stronger inhibitions by vegetables and fruit juices than WJ.

The data suggest that the inhibitory activities of WJ against digestive enzymes might delay carbohydrate and lipid hydrolysis in the gastrointestinal tract, which would in turn decrease absorption of glucose and fatty acids. WJ may, therefore, be a useful dietary supplement potentially capable of inhibiting $\alpha$-glucosidase, $\alpha$-amylase, and lipase.

\subsection{TPC, TFC and in vitro antioxidant activity}

TPC value of WJ (Table 3) was comparable to that of a commercial juice (2.5 mg mL ${ }^{-1}$ ) (Tabart, Kevers, Pincemail, Defraigne, \& Dommes, 2009). Lower TPC and TFC values were found in vegetable juices studied by other authors (0.11-0.58 and 0.08-0.48 $\mathrm{mg} \mathrm{mL}^{-1}$, respectively) (Simsek et al., 2014; Tiwari et al., 2013).
The increased free-radical production by oxidative stress is associated with the initiation and progression of diabetes and related complications (Podsedek et al., 2014; Tiwari et al., 2013). Therefore, supplementation with radical scavenging antioxidants can be useful for prevention and/or reduction of oxidative stress involved in this metabolic disorder. High antioxidant activities for watercress extracts have been previously reported (Boligon et al., 2013; Isabelle et al., 2010; Martínez-Sánchez et al., 2008; Payne et al., 2013; Pereira et al., 2011; Tiveron et al., 2012). Generally, antioxidant measurements obtained from water extracts were lower than those obtained with organic solvents (Oroian \& Escriche, 2015; Sulaiman, Sajak, Ooi, \& Seow, 2011). This is in agreement with the present results (Table 3). Antioxidant activities of WJ (Table 3) were at the lower end of the range documented for other vegetable juices (5-2,260 $\mu \mathrm{mol} T \mathrm{TE}^{-1}$ ) (Simsek et al., 2014; Tabart et al., 2009).

\section{4 | CONCLUSIONS}

Thirty-nine compounds (phenolic and non-phenolic) were characterized in WJ. HCAs were the main class of polyphenols, followed by flavonols (isorhamentin and quercetin derivatives), which is a different trend from that reported in the literature.Inhibitiory activities towards digestive enzymes may have been due to polyphenols, however other minor compounds present in the juice could also be involved. This is the first report on digestive enzyme inhibitory activity by WJ, suggesting its potential as a viable source of phytochemicals for the management of hyperglycaemia and hyperlipidaemia by dietary inhibition of sugar and fat absorption. Excessive ingestion of raw watercress should be avoided due to relatively high contents of oxalic acid, although this particular cultivar was at the lower end of the range.

\section{ACKNOWLEDGMENTS}

The authors are grateful to Sonae MC for supplying the watercress samples used in this study. Vítor Spínola is grateful to Fundação para a Ciência e a Tecnologia (FCT, Portugal) for a Ph.D. grant SFRH/BD/84672/2012.

\section{CONFLICT OF INTEREST}

The authors confirm that this article has no conflicts of interest.

\section{REFERENCES}

Abirami, A., Nagarani, G., \& Siddhuraju, P. (2014). In vitro antioxidant, anti-diabetic, cholinesterase and tyrosinase inhibitory potential of fresh juice from Citrus hystrix and C. maxima fruits. Food Science and Human Wellness, 3, 16-25.

Aires, A., Carvalho, R., Rosa, E. A. S., \& Saavedra, M. J. (2013). Phytochemical characterization and antioxidant properties of baby-leaf watercress produced under organic production system. CyTA-Journal of Food, 11, 343-351.

Alakolanga, A. G. A. W., Kumar, N. S., Jayasinghe, L., \& Fujimoto, Y. (2015). Antioxidant property and $\alpha$-glucosidase, $\alpha$-amylase and lipase inhibiting activities of Flacourtia inermis fruits: Characterization of 
malic acid as an inhibitor of the enzymes. Journal of Food Science and Technology, 52, 8383-8388.

Arulselvan, P., Ghofar, H. A. A., Karthivashan, G., Halim, M. F. A., Ghafar, M. S. A., \& Fakurazi, S. (2014). Antidiabetic therapeutics from natural source: A systematic review. Biomedicine \& Preventive Nutrition, 4, 607-617.

Boligon, A. A., Janovik, V., Pivetta, C. R., Pereira, R. P., Da Rocha, J. B. T., \& Athayde, M. L. (2013). HPLC analysis of polyphenolic compounds and antioxidant activity in Nasturtium officinale. Inernational Journal of Food Properties, 16, 61-69.

Cartea, M. E., Francisco, M., Soengas, P., \& Velasco, P. (2011). Phenolic compounds in Brassica vegetables. Molecules, 16, 251-280.

Díaz-García, M. C., Obon, J. M., Castellar, M. R., Collado, J., \& Alacid, M. (2013). Quantification by UHPLC of total individual polyphenols in fruit juices. Food Chemistry, 138, 938-949.

Escardó, M., \& Cuadra, M. (2014). Detox juicing: 3-Day, 7-day, and 14day cleanses for your health and well-being. Skyhorse Publishing. New York.

Funke, I., \& Melzig, M. F. (2005). Effect of different phenolic compounds on $\alpha$-amylase activity: Screening by microplate-reader based kinetic assay. Pharmazie, 60, 796-797.

Getting, J. E., Gregoire, J. R., Phul, A., Kasten, M. J., Calbom, C., Keane, M., Lalanne, J., et al. (2013). Oxalate nephropathy due to "juicing": Case report and review. American Journal of Medicine, 126, 768-772.

Harbaum, B., Hubbermann, E. M., Wolff, C., Herges, R., Zhu, Z., \& Schwarz, K. (2007). Identification of flavonoids and hydroxycinnamic acids in pak choi varieties (Brassica campestris L. ssp. chinensis var. communis) by HPLC-ESI-MSn and NMR and their quantification by HPLC-DAD. Journal of Agricultural and Food Chemistry, 55, 8251-8260.

Isabelle, M., Lee, B. L., Lim, M. T., Koh, W. P., Huang, D., \& Ong, C. N. (2010). Antioxidant activity and profiles of common vegetables in Singapore. Food Chemistry, 120, 993-1003.

Khan, H., Jan, S. A., Javed, M., Shaheen, R., Khan, Z., Ahmad, A., Safi, S. Z., et al. (2016). Nutritional composition, antioxidant and antimicrobial activities of selected wild edible plants. Journal of Food Biochemistry, 40, 61-70.

Kim, Y. S., Lee, Y. M., Kim, H., Kim, J., Jang, D. S., Kim, J. H., \& Kim, J. S. (2010). Anti-obesity effect of Morus bombycis root extract: Antilipase activity and lipolytic effect. Journal of Ethnopharmacology, 130, 621-624.

Kumar, D. A., Anusha, S. V., Oruganti, S., Deshpande, M., Zehra, A., \& Tiwari, A. K. (2015). Raw versus cooked vegetable juice. Nutrafoods, 14, 27-38.

Kwon, D., Kim, G. D., Kang, W., Park, J. E., Kim, S. H., Choe, E., Kim, J. I., et al. (2014). Pinoresinol diglucoside is screened as a putative $\alpha$-glucosidase inhibiting compound in Actinidia arguta leaves. Journa, of the Korean Society for Applied Biological Chemistry, 57, 473-479.

Lee, S. G., Kim, J. H., Son, M. J., Lee, E. J., Park, W. D., Kim, J. B., Lee, S. P., et al. (2013). Influence of extraction method on quality and functionality of broccoli juice. Preventive Nutrition and Food Science, 18, 133-138.

Lin, L. Z. \& Harnly, J. M. (2010). Phenolic component profiles of mustard greens, Yu choy, and 15 other Brassica vegetables. Journal of Agricultural and Food Chemistry, 58, 6850-6857.

Llorach, R., Martínez-Sánchez, A., Tomás-Barberán, F. A., Gil, M. I., \& Ferrers, F. (2008). Characterisation of polyphenols and antioxidant properties of five lettuce varieties and escarole. Food Chemistry, 108, 1028-1038.

Llorent-Martínez, E. J., Spínola, V., Gouveia, S., \& Castilho, P. C. (2015). HPLC-ESI-MSn characterization of phenolic compounds, terpenoid saponins, and other minor compounds in Bituminaria bituminosa. Industrial Crops and Products, 69, 80-90.

Lo Piparo, E., Scheib, H., Frei, N., Williamson, G., Grigorov, M. \& Chou, C.J. (2008). Flavonoids for controlling starch digestion: structural requirements for inhibiting human alpha-amylase. Journal of Medicinal Chemistry, 51, 3555-3561.

Mahmood, N. (2015). A review of $\alpha$-amylase inhibitors on weight loss and glycemic control in pathological state such as obesity and diabetes. Comparative Clinical Pathology, 1-12.

Martínez-Sánchez, A., Gil-Izquierdo, A., Gil, M. I., \& Ferreres, F. (2008). A comparative study of flavonoid compounds, vitamin C, and antioxidant properties of baby leaf Brassicaceae species. Journal of Agricultural and Food Chemistry, 56, 2330-2340.

Mousa-Al-Reza Hadjzadeh, Z. R., Moradi, R., \& Ghorbani, A. (2015). Effects of hydroalcoholic extract of Watercress (Nasturtium officinale) leaves on serum glucose and lipid levels in diabetic rats. Indian Journal of Physiology and Pharmacology, 59, 223-230.

Olsen, H., Aaby, K., \& Borge, G. I. (2009). Characterization and quantification of flavonoids and hydroxycinnamic acids in curly kale (Brassica oleracea L. Convar. acephala var. sabellica) by HPLC-DADESI-MSn. Journal of Agricultural and Food Chemistry, 57, 2816-2825.

Oroian, M. \& Escriche, I. (2015). Antioxidants: Characterization, natural sources, extraction and analysis. Food Research International, 74, 10-36.

Payne, A. C., Mazzer, A., Clarkson, G. J. J., \& Taylor, G. (2013). Antioxidant assays-consistent findings from FRAP and ORAC reveal a negative impact of organic cultivation on antioxidant potential in spinach but not watercress or rocket leaves. Food Science \& Nutrition, 1, 439-444.

Pereira, C., Barros, L., Carvalho, A. M., \& Ferreira, I. C. F. R. (2011). Nutritional composition and bioactive properties of commonly consumed wild greens: Potential sources for new trends in modern diets. Food Research International, 44, 2634-2640.

Pinela, J., Barreira, J. C. M., Barros, L., Antonio, A. L., Carvalho, A. M., Oliveira, M. B. P. P., \& Ferreira, I. C. F. R. (2016). Postharvest quality changes in fresh-cut watercress stored under conventional and inert gas-enriched modified atmosphere packaging. Postharvest Biology and Technology, 112, 55-63.

Podsedek, A., Majewska, I., Redzynia, M., Sosnowska, D., \& Koziołkiewicz, M. (2014). In vitro inhibitory effect on digestive enzymes and antioxidant potential of commonly consumed fruits. Journal of Agricultural and Food Chemistry, 62, 4610-4617.

Santos, J., Oliveira, M. B. P. P., Ibáñez, E., \& Herrero, M. (2014). Phenolic profile evolution of different ready-to-eat baby-leaf vegetables during storage. Journal of Chromatography A, 1327, 118-131.

Shahrokhi, N., Hadad, M. K., Keshavarzi, Z., \& Shabani, M. (2009). Effects of aqueous extract of watercress on glucose and lipid Plasma in streptozotocin induced diabetic rats. Pakistan Journal of Physiology, 5, 6-10.

Simsek, S., El, S. N., Kancabas Kilinc, A., \& Karakaya, S. (2014). Vegetable and fermented vegetable juices containing germinated seeds and sprouts of lentil and cowpea. Food Chemistru, 156, 289-295.

Spínola, V., Mendes, B., Câmara, J. S., \& Castilho, P. C. (2013). Effect of time and temperature on vitamin $C$ stability in horticultural extracts. UHPLC-PDA vs iodometric titration as analytical methods. LWTFood Science and Technology, 50, 489-495.

Spínola, V., Pinto, J., \& Castilho, P. C. (2015). Identification and quantification of phenolic compounds of selected fruits from Madeira Island by HPLC-DAD-ESI-MSn and screening for their antioxidant activity. Food Chemistry, 173, 14-30. 
Sulaiman, S. F., Sajak, A. A. B., Ooi, K. L., \& Seow, E. M. (2011). Effect of solvents in extracting polyphenols and antioxidants of selected raw vegetables. Journal of Food Composition and Analysis, 24, 506-515.

Tabart, J., Kevers, C., Pincemail, J., Defraigne, J., \& Dommes, J. (2009). Comparative antioxidant capacities of phenolic compounds measured by various tests. Food Chemistry, 113, 1226-1233.

Tiveron, A. P., Melo, P. S., Bergamaschi, K. B., Vieira, T. M. F. S., Regitano-D'arce, M. A. B., \& Alencar, S. M. (2012). Antioxidant activity of Brazilian vegetables and its relation with phenolic composition. International Journal of Molecular Sciences, 13, 8943-8957.

Tiwari, A. K., Jyothi, A. L., Tejeswini, V. B., Madhusudana, K., Kumar, D. A., Zehra, A., \& Agawane, S. B. (2013). Mitigation of starch and glucose-induced postprandial glycemic excursion in rats by antioxidant-rich green-leafy vegetables' juice. Pharmacognosy Magazine, 9, S66-S73.

Verardo, G., Duse, I., \& Callea, A. (2009). Analysis of underivatized oligosaccharides by liquid chromatography/electrospray ionization tandem mass spectrometry with post-column addition of formic acid. Rapid Communications in Mass Spectrometry, 23, 1607-1618.

Vinha, A. F., Alves, R. C., Barreira, S. V. P., Costa, A. S. G., \& Oliveira, M. B. P. P. (2015). Impact of boiling on phytochemicals and antioxidant activity of green vegetables consumed in the Mediterranean diet. Food \& Function, 6, 1157-1163.

Yang, D., Liang, J., Xie, H., \& Wei, X. (2016). Norsesquiterpenoids and triterpenoids from strawberry cv. Falandi. Food Chemisry, 203, 67-72.

\section{SUPPORTING INFORMATION}

Additional Supporting Information can be found online in the supporting information tab for this article.

How to cite this article: Spínola V, Pinto J, Castilho PC. In vitro studies on the effect of watercress juice on digestive enzymes relevant to type 2 diabetes and obesity and antioxidant activity. J Food Biochem. 2017;41:e12335. https://doi.org/10.1111/jfbc. 12335 